\title{
Genetic Background Strongly Influences the Bone Phenotype of P2X7 Receptor Knockout Mice
}

\author{
Susanne Syberg, ${ }^{1,2}$ Solveig Petersen, ${ }^{1}$ Jens-Erik Beck Jensen, ${ }^{2}$ \\ Alison Gartland, ${ }^{3}$ Jenni Teilmann, ${ }^{2}$ Iain Chessell, ${ }^{4}$ Thomas H. Steinberg, ${ }^{5}$ \\ Peter Schwarz, ${ }^{1,6}$ and Niklas Rye Jørgensen ${ }^{1,2}$ \\ ${ }^{1}$ Departments of Diagnostics and Medicine, Research Centre of Ageing and Osteoporosis, Glostrup University Hospital, \\ 2600 Glostrup, Denmark \\ ${ }^{2}$ Osteoporosis and Bone Metabolic Unit, Departments of Endocrinology and Clinical Biochemistry, Hvidovre University Hospital, \\ 2650 Hvidovre, Denmark \\ ${ }^{3}$ Mellanby Centre for Bone Research, The University of Sheffield, Sheffield S10 2TN, UK \\ ${ }^{4}$ NeuroScience and MedImmune, Milstein Building, Granta Park, Cambridge CB21 6GH, UK \\ ${ }^{5}$ Department of Internal Medicine, Washington University School of Medicine and St. Louis Veterans Affairs Medical Center, \\ St. Louis, MO 63106, USA \\ ${ }^{6}$ Faculty of Health Sciences, University of Copenhagen, 2200 Copenhagen, Denmark
}

Correspondence should be addressed to Susanne Syberg, syberg@ruc.dk

Received 31 March 2012; Revised 28 June 2012; Accepted 2 July 2012

Academic Editor: Elena Adinolfi

Copyright (C) 2012 Susanne Syberg et al. This is an open access article distributed under the Creative Commons Attribution License, which permits unrestricted use, distribution, and reproduction in any medium, provided the original work is properly cited.

\begin{abstract}
The purinergic P2X7 receptor is expressed by bone cells and has been shown to be important in both bone formation and bone resorption. In this study we investigated the importance of the genetic background of the mouse strains on which the P2X7 knockout models were based by comparing bone status of a new BALB/cJ P2X7 ${ }^{-/-}$strain with a previous one based on the C57BL/6 strain. Female four-month-old mice from both strains were DXA scanned on a PIXImus densitometer; femurs were collected for bone strength measurements and serum for bone marker analysis. Bone-related parameters that were altered only slightly in the B6 $\mathrm{P} 2 \mathrm{X}^{-/-}$became significantly altered in the BALB/cJ P2X7 $7^{-/-}$when compared to their wild type littermates. The BALB/cJ P2X7 ${ }^{-/-}$ showed reduced levels of serum C-telopeptide fragment (s-CTX), higher bone mineral density, and increased bone strength compared to the wild type littermates. In conclusion, we have shown that the genetic background of $\mathrm{P} 2 \mathrm{X} 7^{-1-}$ mice strongly influences the bone phenotype of the $\mathrm{P} 2 \mathrm{X}^{-/-}$mice and that $\mathrm{P} 2 \mathrm{X} 7$ has a more significant regulatory role in bone remodeling than found in previous studies.
\end{abstract}

\section{Introduction}

In bone, endogenous nucleotides, such as ATP and UTP, are released from many types of cells, including bone cells [1, $2]$. Nucleotides are released in response to a number of stimuli including inflammation $[3,4]$ and mechanical stimulation [5-7]. They act as autocrine and paracrine signaling molecules by activating purinergic $(\mathrm{P} 2)$ receptors [8]. Bone cells express several types of P2 receptors [9], allowing them to respond differently to nucleotides, depending on the types of nucleotide present, their concentration, and the duration of exposure $[8,9]$. The $\mathrm{P} 2 \mathrm{X} 7$ receptor subtype is probably one of the most important $\mathrm{P} 2$ receptors in the regulation of bone turnover. It is most abundant in cells of haematopoetic origin [10], including osteoclasts $[8,11]$, but also in osteoblasts that are of mesenchymal origin [12-14].

Several roles of P2X7 have been suggested including ATPinduced apoptosis $[12,15,16]$, maturation of interleukin- $1 \beta$, and its subsequent release [17]. Low agonist concentrations lead to low-level activation of P2X7 receptors and might initiate osteoclast formation through activation of pathways initiating production of transcription factors $[18,19]$. 
Prolonged exposure to high agonist concentrations induces the formation of large pores in the membrane, permeable to hydrophilic molecules as large as $900 \mathrm{Da}[20,21]$. P2X7 receptors are expressed in both osteoclast precursors and active osteoclasts $[8,11,22]$. Therefore, in addition to activating the apoptotic pathway, the $\mathrm{P} 2 \mathrm{X} 7$ receptor could play a role in osteoclast development $[23,24]$ and activation [25].

To further explore the role of the P2X7 receptor in the regulation of the skeletal system, the bone phenotype of two mouse models with ablation of the P2X7 receptor was examined $[13,22,26]$. Both of these exhibited a skeletal phenotype different from the genetic background strain. The P2X7 knock-out model first published by Solle et al. [27] showed reduced total bone mineral content (BMC), decreased periosteal bone formation, and increased bone resorption [13], which resembles the effects of disuse on the skeleton. In line with this it was shown that $\mathrm{P} 2 \mathrm{X} 7^{-/-}$ mice have impaired response to mechanical loading [26]. The effects are partially due to increased osteoclast numbers which were further supported by in vitro studies showing that the $\mathrm{P} 2 \mathrm{X} 7$ receptor is not necessary for murine osteoclast formation [13]. The second murine P2X7 knock-out model generated by Chessell et al. [28] shows a different bone phenotype with increased cortical thickness of the tibial shaft, but surprisingly no changes in total BMD [22].

The contradicting observations have been attributed to the dissimilar sample sizes, methods of the gene knockout, and different genetic backgrounds of the inbred strains used to generate the mice. Solle's $\mathrm{P} 2 \mathrm{X}^{-/-}$mice were generated on 129/Ola, C57Bl/6 (B6), and DBA/2 mixed genetic background but afterwards maintained on the $\mathrm{B} 6 \mathrm{xDBA} / 2$ background $[13,27]$, hereafter called DBAxB6 $\mathrm{P} 2 \mathrm{X}^{-/-}$. The $\mathrm{P} 2 \mathrm{X}^{-/-}$mice generated by Chessell et al. were maintained on B6 background but originate from a B6/129 hybrid [28], hereafter called $\mathrm{B} 6 \mathrm{P} 2 \mathrm{X}^{-/-}$.

Interestingly, mice of the DBA and B6 background have a naturally occurring mutation in the $\mathrm{P} 2 \mathrm{X} 7$ receptor as shown by Adriouch et al. [29]. Presence of the mutation impairs the normal function of the receptor; HEK cells transfected with constructs of both genotypes showed that ATP-induced pore formation was reduced by $50 \%$ in cells carrying the mutated allele (451L) [29]. In osteoclasts from mouse strains carrying the $451 \mathrm{~L}$ allele we found a reduction in pore-forming activity compared to osteoclasts from strains carrying the $\mathrm{P} 451$ allele [30]. In murine thymocytes the P451L mutation affects the mechanism of apoptosis acting through the pore formation induced by ATP [31]. As the response of the P2X7 receptor to ATP is lower in cells harbouring the 451L allele of the P2X7 gene, consequently the observed effects of the $\mathrm{P} 2 \mathrm{X}^{-/-}$in the two models may have been underestimated in the published studies. By introducing a different genetic background to a $\mathrm{P} 2 \mathrm{X}^{-1-}$ model a more pronounced bone phenotype could maybe be found.

In support of this, we recently showed that $\mathrm{DBA} / 2$ and B6 mice have low BMD along with impaired bone strength [30], which could make it difficult to detect ovariectomyinduced bone loss in mouse models of postmenopausal osteoporosis. Therefore, both the B6 and DBA are less suitable as mouse models of osteoporosis. Of the four inbred strains of mice that have been reported to have the P451 allelic genotype [29], only $129 \mathrm{X} 1 / \mathrm{SvJ}$ and $\mathrm{BALB} / \mathrm{cJ}$ proved ideal for a new $\mathrm{P} 2 \mathrm{X}^{-/-}$strain. Both strains had high baseline BMD, relatively strong bones and high trabecular bone volume [30]. Since the $129 \mathrm{X} 1 / \mathrm{SvJ}$ strain is resistant to cancellous bone loss induced by ovariectomy [32] only the $\mathrm{BALB} / \mathrm{cJ}$ strain is suitable as a candidate strain for the generation of a new P2X7 knock-out model. The BALB/cJ mice are characterized by having high BMD, high Tb.Th, and trabecular numbers along with strong bones. Since the $\mathrm{BALB} / \mathrm{cJ}$ mice clearly respond to ovariectomy with bone loss [33], it is well suited for studying the bone specific effect of P2X7 knock-out.

Therefore, the overall aim of this study was to generate a new $\mathrm{P} 2 \mathrm{X}^{-1-}$ strain with a genetic background not harbouring the P451L mutation subsequent to characterizing the $\mathrm{BALB} / \mathrm{cJ} \mathrm{P} 2 \mathrm{X}^{-/-}$mice and comparing the bone phenotypes of this model with that of the $\mathrm{B} 6 \mathrm{P} 2 \mathrm{X}^{-/-}$.

\section{Materials and Methods}

2.1. Animals. Female mice of the $\mathrm{B} 6 \mathrm{P}_{2} \mathrm{X}^{-/-}$strain [28] were kindly provided by GlaxoSmithKline and crossed into the BALB/cJ inbred strain from Jackson Laboratories (Bar Harbor, ME) for five generations. Founders were selected by PCR for the knockout of exon of the P2X7 gene. Since the mice generated were only insipient congenic with the BALB/ cJ genome ( $\sim 97 \%)$, wild type littermates from heterozygote breeding couples were used as control groups in both strains, instead of inbred B6 or BALB/cJ.

Requests for BALB/cJ P2X7 animals should be addressed to Niklas Rye Jørgensen (Niklas@dadlnet.dk). The authors do not currently have access to $\mathrm{B} 6 \mathrm{P} 2 \mathrm{X}^{-1-}$ animals, so requests for these should be directed to GlaxoSmithKline.

2.2. Study Protocol. All animal procedures were approved by The Danish Animal Welfare Council prior to initiating the experiments (protocol: 2002/561-634 and 2006/561-1209). Female mice ( $n=15$ mice per strain) were kept at a $12: 12$ hour light/dark cycle at $20 \pm 0.7^{\circ} \mathrm{C}$, fed the Purina mouse diet formula 5K52 (Purina, St. Louis, MO), and had access to tap water ad libitum. Ten and two days before sacrifice, animals were injected with $25 \mathrm{mg} / \mathrm{kg}$ tetracycline i.p. or $20 \mathrm{mg} / \mathrm{kg}$ calcein i.p., respectively, in order to label formative surfaces of bone for dynamic bone histomorphometry. At the age of 120 days, they were starved overnight (to minimize biological variation in bone markers) and euthanized by $\mathrm{CO}_{2}$. Blood was collected into $2 \mathrm{~mL}$ syringes by cardiac puncture, and serum was collected for later measurements of bone markers. The animals were scanned on the PIXImus (Lunar Corp.) densitometer shortly after blood was collected.

2.3. $\mathrm{P} 2 \mathrm{X}^{-/-}$Genotyping. $\mathrm{P} 2 \mathrm{X}^{-/-}$animals of both strains (B6 and the $\mathrm{BALBC} / \mathrm{J}$ ) were genotyped by PCR using the protocol outlined in the following. Earpieces or tail parts were used for DNA isolation with the QIAamp DNA Blood Mini Kit (Qiagen), which was used as template in PCR 
reactions. The primers used were Forward primer (P2X7GT1): 5' GGG GTG GTG AAG AAA TGA A 3', Reverse primer (P2X7-GT2): 5' GGA TGT GCT GCA AGG CGA TT 3', Reverse primer (P2X7-GT3): 5' CCA CTT GAC GGT GCC ATA $3^{\prime}$. The P2X7-GT1 and P2X7-GT2 primers amplify a 2473 bp product for the $\mathrm{P} 2 \mathrm{X}^{-/-}$mouse, while the P2X7-GT1 and P2X7-GT3 primers amplify a 2447 bp product for the wild type mouse. Because of the similarity of the two bands the two primer pairs were used in two different PCR reactions. The samples were amplified using a PCR cycler (MJ Research Inc.) with the following program. After preheating at $95^{\circ} \mathrm{C}$ for $15 \mathrm{~min}, 35$ cycles were run, with denaturation at $94^{\circ} \mathrm{C}$, annealing at $56^{\circ} \mathrm{C}$ for $1 \mathrm{~min}$, extension at $72^{\circ} \mathrm{C}$ for $1 \mathrm{~min}$ before final extension for $10 \mathrm{~min}$ at $72^{\circ} \mathrm{C}$. PCR products were loaded on a $1 \%$ agarose gel (IBI agarose, Shelton Scientific Inc.) for electrophoresis. The amplicons were visualized under UV light using the GeneGenius gel imaging system from Syngene.

2.4. Bone Formation and Resorption Markers. To investigate possible differences in bone formation markers between the genotypes, osteocalcin was measured in serum samples in duplicate using the Mouse Osteocalcin RIA Reagents from Biomedical Technologies, Inc. (Stoughton, MA), following the protocol supplied with the reagents. Interassay CV was $12 \%$ and intraassay $\mathrm{CV}$ was $6 \%$.

Bone resorption as expressed by fragments of type I collagen (CTX) in mouse serum was measured in duplicate using the RatLaps Elisa Assay (C-telopeptide collagen type I fragment Assay) developed by Nordic Bioscience Diagnostics (Herlev, Denmark) and following the procedure supplied with the kit. Interassay CV was $14.8 \%$ and intraassay $\mathrm{CV}$ was $9.2 \%$.

Alkaline phosphatase activity was measured in duplicate in mouse serum using the Alkaline phosphatase Reagent Kit (Sigma). The kit measures total alkaline phosphatase activity and does not distinguish the different organ-specific subtypes. Alkaline Phosphatase activity was measured directly on the serum in the multiwell plates, using a slight modification of the standard clinical chemistry procedure. Serum replicas were diluted with alkaline buffer solution, and substrate solution was added to each well, and the plate was incubated at $37^{\circ} \mathrm{C}$ for $30 \mathrm{~min}$. Finally $2.0 \mathrm{M} \mathrm{NaOH}$ was added to each well to stop the reaction. Absorbance was measured on a plate reader at $405 \mathrm{~nm}$. Interassay CV was $5.9 \%$ and intra-assay CV was $2.4 \%$.

2.5. Bone Strength Measurements. On the day of sacrifice the mouse femurs were collected, cleaned for soft tissue, wrapped in saline moistened gauze in a tube, and frozen at $-20^{\circ} \mathrm{C}$ for later ex vivo biomechanical measurements, as described earlier [34]. The strength of the femoral diaphysis was determined by a 3-point bending test on a Lloyd Instruments compression device (LR50K, Lloyd Instruments, Fareham, UK), after rehydration in a saline solution at room temperature. Load-deformation curves were generated, and maximal load was recorded at a speed of $2 \mathrm{~mm}$ per minute with a $100 \mathrm{~N}$ load cell.
2.6. Bone Histomorphometry. To investigate histologic and morphometric changes in the $\mathrm{P} 2 \mathrm{X}^{-1-}$ models histomorphometric analyses were performed. In short the total spines and tibias were collected and fixed in $70 \%$ ethanol at $5^{\circ} \mathrm{C}$. After methyl-methacrylate embedding, bones were sectioned into $7 \mu \mathrm{m}$ thick slices on a Polycut $\mathrm{E}$ (heavy-duty microtome) and mounted on slides. Five subsequent slides were stained with Goldner-Trichrome for determination of bone volume in percentage of total volume (BV/TV, \%), cortical thickness (C.Th, $\mu \mathrm{m}$ ), trabecular thickness (Tb.Th, $\mu \mathrm{m}$ ), and eroded surface as percentage of bone surface (ES/BS). Five slides from each bone were left unstained for quantification of mineralizing surfaces as percentage of bone surface (MS/BS, $\%)$ under fluorescent light. Further, mineral appositional rate (MAR, $\mu \mathrm{m} /$ day) was calculated. The previously mentioned indices were determined using an Olympus BX51 microscope equipped with a C.A.S.T.-Grid system and reported according to standard bone histomorphometry nomenclature.

2.7. Statistics. Statistical analyses were performed using the SPSS software, v.11.5. Standard parametric tests were used. Differences were considered statistically significant when $P \leq$ 0.05 . Simple descriptives were presented as means \pm standard error of the mean (SEM). The two types of knockout animals were compared to the respective wild type animals by Student's $t$-test.

\section{Results}

3.1. Comparison of the Two $\mathrm{P} 2 X 7^{+/+}$Strains. The new $\mathrm{P} 2 \mathrm{X}^{-/-}$ strain was made by backcrossing the $\mathrm{B} 6 \mathrm{P} 2 \mathrm{X}^{-/-}$mice generated by Chessell et al. [28] into the BALB/cJ inbred strain for five generations, hereafter called BALB/cJ P2X7 ${ }^{-/-}$. As a point of reference there were no significant differences between the wild type $\left(\mathrm{P} 2 \mathrm{X}^{+/+}\right)$mice of the two strains used for the knockout in the majority of assessed bone parameters (Table 1), but the BMD, femoral strength, and concentration of bone markers were significantly lower in the B6 strain (Table 1, Figures 1(b) and 1(c)) than in the BALB/cJ. Furthermore, bone resorption (levels of s-CTX and $\mathrm{ES} / \mathrm{BS} \%$ ) were lower in the wild type B6 compared to the wild type BALB/cJ strain (Tables 1 and 2 and Figure 1(d)), and the bone formation markers alkaline phosphatase and osteocalcin were decreased in the B6 (Table 1).

3.2. $B 6 P 2 X 7^{-/-}$Mice. There were no significant differences in the basic characteristics such as weight, length, and body composition between the two genotypes of the B6 P2X7 animals (data not shown). The markers of bone resorption and bone formation did not alter significantly when P2X7 was ablated in the $\mathrm{B} 6$ mice (Table 2). The increase in whole body $\mathrm{BMD}(4.5 \%, P=0.011)$ in $\mathrm{B} 6 \mathrm{P} 2 \mathrm{X}^{-1-}$ compared to the $\mathrm{P} 2 \mathrm{X}^{+/+}$animals (Figure $1(\mathrm{a})$ ) was accompanied by significant increased bone strength in $\mathrm{B} 6 \mathrm{P}^{2} \mathrm{X}^{-/-}, 18.22 \mathrm{~N}$ compared to $16.29 \mathrm{~N}$ in $\mathrm{B} 6 \mathrm{P} 2 \mathrm{X}^{+/+}(P=0.018)$. The histomorphometric analysis of bone indices in the vertebrae showed only significant increase in $\mathrm{Tb}$.Th in $\mathrm{B} 6 \mathrm{P} 2 \mathrm{X}^{-/-}$ 


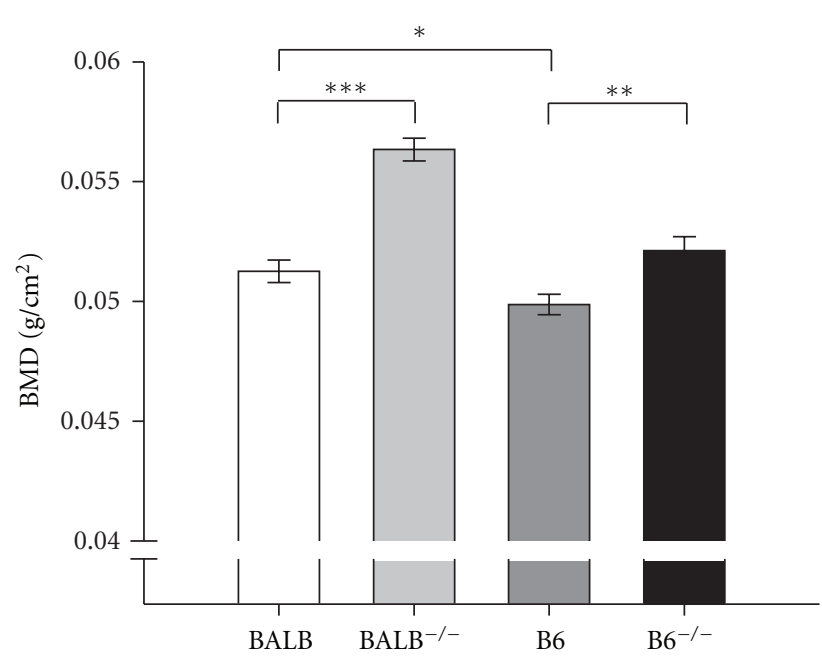

(a)

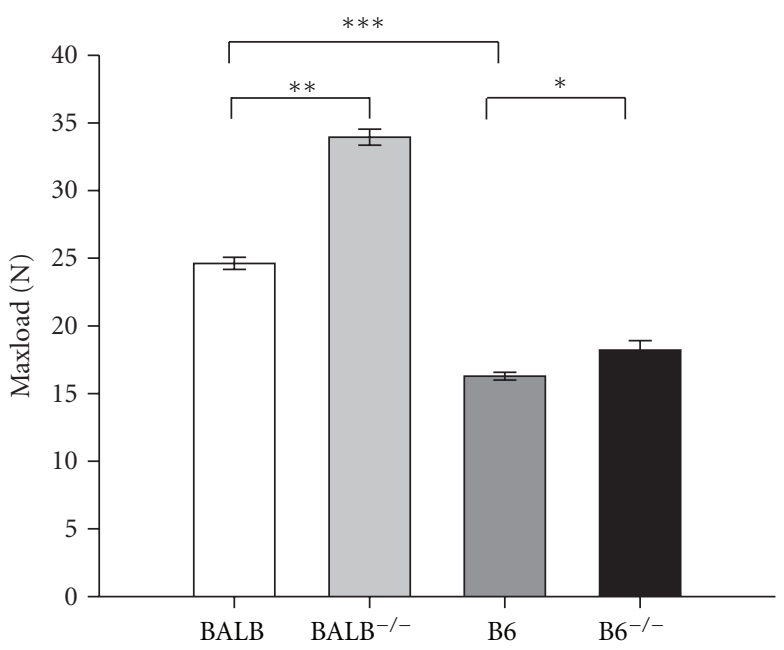

(c)

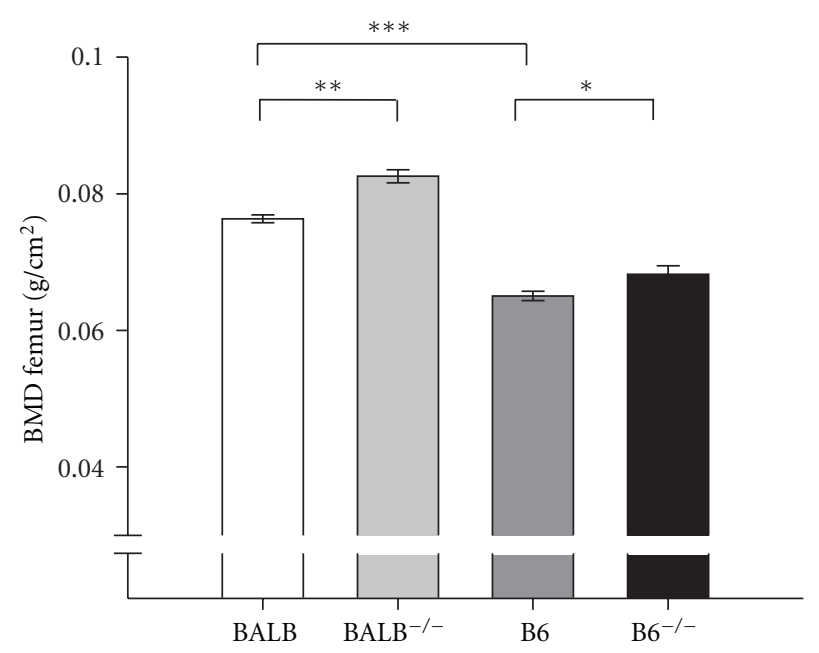

(b)

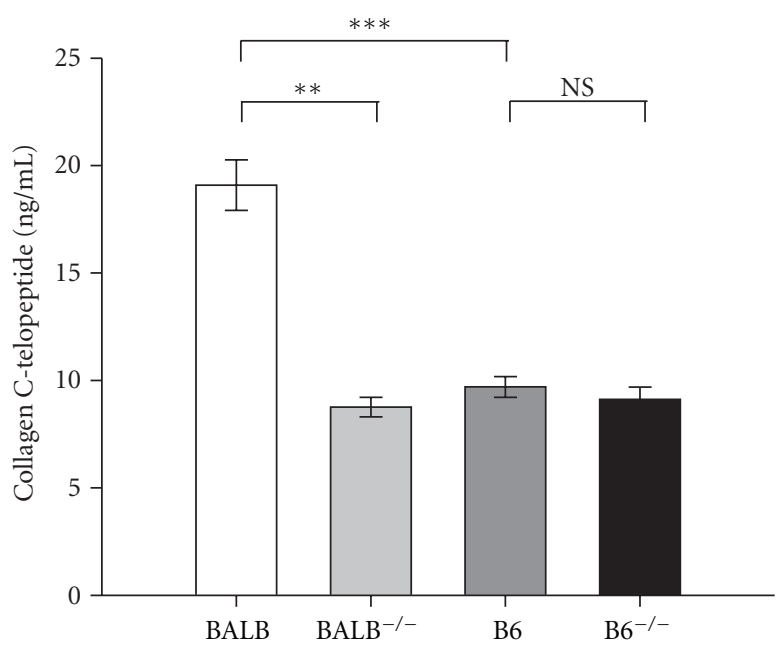

(d)

FIGURE 1: Bone mineral density, bone strength, and serum concentration of the resorption marker in the P2X7 ${ }^{-/-}$in the strains BALB/cJ and B6 compared to their wild type littermates, displayed as means \pm SEM. (a) Bone mineral density in BALB/cJ and B6 measured by DXA scanning on the PIXImus. The mice homozygote for the P2X7 deletion in both strains had significant higher BMD than the wild type. There was also significant difference in BMD between the two wild type groups. (b) Bone mineral density in the femoral region of BALB/cJ and B6 measured by DXA scanning on the PIXImus. The mice homozygote for the P2X7 deletion in both strains had higher BMD than the wild type; however it was only significant in the BALB/cJ strain. There were also significant differences in BMD between the two wild type groups. (c) Strength of femurs in BALB/cJ and B6 measured by a three-point bending test. The mice homozygous for the P2X7 deletion in $\mathrm{BALB} / \mathrm{cJ}$ had significant stronger bones than the wild type BALB/cJ. B6 wild type bones were significantly weaker in the test and only a small significant difference when compared to the knockout group. (d) Concentration of s-CTX (ng/mL) in BALB/cJ and B6. There were no significant differences between the wild type and homozygote in the B6 strains. In BALB/cJ the serum concentration was significantly $46 \%$ lower in the $\mathrm{KO}$ animals compared to the wild type.

mice $(P=0.011)$ compared to $\mathrm{B} 6 \mathrm{P} 2 \mathrm{X}^{+/+}$(Table 2$)$. Histomorphometric analysis of the proximal tibia revealed that in resemblance with the vertebrae $\mathrm{Tb}$.Th was increased ( $32.3 \mu \mathrm{m}$ to $35.5 \mu \mathrm{m})$ however not significant in this region $(P=0.119)$. As seen on Figure 2, the thickness of the tibial cortex was increased to $162.6 \mu \mathrm{m}$ in $\mathrm{B} 6 \mathrm{P} 2 \mathrm{X}^{-/-} \mathrm{com}-$ pared to $127.4 \mu \mathrm{m}$ in $\mathrm{B} 6 \mathrm{P}^{2} \mathrm{X}^{+/+}(P<0.001)$. When the histomorphometric indices of $\mathrm{B} 6 \mathrm{P} 2 \mathrm{X}^{-1-}$ were compared to $\mathrm{B} 6 \mathrm{P} 2 \mathrm{X}^{+/+}$, the changes were of different amplitude and direction in the two regions, tibia and vertebrae, as presented in Table 2.
3.3. BALB/cJ P2X7 $27^{-1-}$ Mice. First, we analyzed the data concerning the basic characteristics such as weight, length, and body composition (lean versus fat tissue). No significant difference between $\mathrm{BALB} / \mathrm{cJ} \mathrm{P} 2 \mathrm{X}^{-/}$mice and wild type littermates was found (Table 1). The total BMD in BALB/cJ $\mathrm{P} 2 \mathrm{X}^{-1-}$ assessed by DXA, was higher compared to wild type animals (Figure 1(a), Table 1); however here the difference between genotypes was higher in the BALB/cJ strain than in the $\mathrm{B} 6$ strain. Also differences in BMC were detected, with the higher value in the knock-outs $(0.470 \mathrm{~g}$ versus $0.558 \mathrm{~g}$, $P<0.001)$, as well as in bone area, again assessed by DXA 
TABLE 1: Basic characteristics from DXA scanning, three-point-bending test, and bone marker analysis.

\begin{tabular}{|c|c|c|c|c|c|c|c|}
\hline & $N$ & Mean & SEM & $N$ & Mean & SEM & $P$ \\
\hline B6 & \multicolumn{3}{|c|}{$\mathrm{B} 6^{+/+}$} & \multicolumn{3}{|c|}{$\mathrm{B}^{-1-}$} & $t$-Test \\
\hline Body weight (g) & 15 & 20.12 & 0.45 & 14 & 21.65 & 1.63 & 0.380 \\
\hline Lean tissue $(\mathrm{g})$ & 15 & 15.6 & 0.3 & 14 & 15.7 & 0.4 & 0.786 \\
\hline Fat tissue (g) & 15 & 4.2 & 0.3 & 14 & 5.5 & 1.5 & 0.427 \\
\hline Fat percentage & 15 & 20.8 & 1.3 & 14 & 22.7 & 3.1 & 0.587 \\
\hline Bone area $\left(\mathrm{cm}^{2}\right)$ & 15 & 9.10 & 0.10 & 14 & 9.07 & 0.14 & 0.847 \\
\hline Whole body BMC (g) & 15 & 0.454 & 0.007 & 14 & 0.473 & 0.012 & 0.179 \\
\hline Whole body BMD $\left(\mathrm{g} / \mathrm{cm}^{2}\right)$ & 15 & 0.0499 & 0.000 & 14 & 0.0521 & 0.0006 & 0.005 \\
\hline Femur length (mm) & 15 & 15.50 & 0.05 & 13 & 15.66 & 0.21 & 0.500 \\
\hline Femoral BMC (g) & 15 & 0.036 & 0.001 & 14 & 0.037 & 0.001 & 0.321 \\
\hline Femoral BMD $\left(\mathrm{g} / \mathrm{cm}^{2}\right)$ & 15 & 0.0650 & 0.0007 & 14 & 0.0682 & 0.0012 & 0.038 \\
\hline Maximal load $(N)$ & 15 & 16.29 & 0.29 & 14 & 18.22 & 0.68 & 0.018 \\
\hline RatLabs (ng/mL) & 15 & 9.7 & 0.5 & 14 & 9.1 & 0.6 & 0.441 \\
\hline ALP concentration $(\mathrm{nmol} / \mathrm{mL})$ & 12 & 247.6 & 13.5 & 13 & 241.0 & 12.7 & 0.727 \\
\hline Osteocalcin $(\mathrm{ng} / \mathrm{mL})$ & 15 & 39.2 & 2.9 & 14 & 44.5 & 2.4 & 0.161 \\
\hline $\mathrm{BALB} / \mathrm{cJ}$ & \multicolumn{3}{|c|}{$\mathrm{BALB} / \mathrm{cJ}^{+/+}$} & \multicolumn{3}{|c|}{$\mathrm{BALB} / \mathrm{cJ}^{-1-}$} & $t$-Test \\
\hline Body weight (g) & 14 & 20.68 & 0.28 & 15 & 20.42 & 0.25 & 0.499 \\
\hline Lean tissue (g) & 14 & 16.3 & 0.2 & 15 & 16.1 & 0.2 & 0.555 \\
\hline Fat tissue (g) & 14 & 3.6 & 0.1 & 15 & 3.3 & 0.1 & 0.069 \\
\hline Fat percentage & 14 & 18.0 & 0.4 & 15 & 17.0 & 0.4 & 0.086 \\
\hline Bone area $\left(\mathrm{cm}^{2}\right)$ & 14 & 9.19 & 0.08 & 15 & 9.90 & 0.13 & $<0.001$ \\
\hline Whole body BMC (g) & 14 & 0.471 & 0.008 & 15 & 0.558 & 0.009 & $<0.001$ \\
\hline Whole body BMD $\left(\mathrm{g} / \mathrm{cm}^{2}\right)$ & 14 & 0.0513 & 0.0005 & 15 & 0.0563 & 0.0005 & $<0.001$ \\
\hline Femur length (mm) & 14 & 15.06 & 0.17 & 15 & 15.61 & 0.16 & 0.029 \\
\hline Femoral BMC (g) & 14 & 0.040 & 0.001 & 15 & 0.044 & 0.001 & 0.004 \\
\hline Femoral BMD $\left(\mathrm{g} / \mathrm{cm}^{2}\right)$ & 14 & 0.0764 & 0.0006 & 15 & 0.0826 & 0.0010 & $<0.001$ \\
\hline Maximal load $(N)$ & 14 & 24.62 & 0.44 & 15 & 33.95 & 0.59 & $<0.001$ \\
\hline RatLabs $(\mathrm{ng} / \mathrm{mL})$ & 14 & 19.1 & 1.2 & 15 & 8.8 & 0.5 & $<0.001$ \\
\hline ALP concentration $(\mathrm{nmol} / \mathrm{mL})$ & 14 & 314.2 & 11.0 & 14 & 270.6 & 15.0 & 0.028 \\
\hline Osteocalcin $(\mathrm{ng} / \mathrm{mL})$ & 14 & 55.9 & 3.1 & 15 & 63.2 & 2.9 & 0.101 \\
\hline
\end{tabular}

analysis, from $9.19 \mathrm{~cm}^{2}$ to $9.90 \mathrm{~cm}^{2}(P<0.001)$. Bone mineral density of the femur was increased by $8.2 \%(P<0.001$, Figure 1(b)), and bone strength was improved as much as $37.9 \%$ in BALB/cJ P2X7 ${ }^{-/-}$animals $(P<0.001$, Figure $1(\mathrm{c}))$ when compared to wild type animals. BALB/cJ $\mathrm{P} 2 \mathrm{X}^{-/-}$mice have low levels of s-CTX, as seen in Figure 1(d) and Table 1; interestingly, it is markedly reduced in BALB/cJ mice (8.76 ng telopeptide/mL serum) compared to wild type animals (19.09 ng telopeptide/mL serum) $(P<0.001)$. The nonbone-specific alkaline phosphatase decreased significantly from $314.2 \mathrm{nmol} / \mathrm{mL}$ to $270.6 \mathrm{nmol} / \mathrm{mL}$ in $\mathrm{BALB} / \mathrm{cJ} \mathrm{P} 2 \mathrm{X}^{-/-}$ mice $(P=0.028)$. There were no significant changes in concentration of the formation markers osteocalcin $(P=0.101$, Table 1). No significant differences for the BALB/cJ strain in any of the bone histomorphometric indices analyzed were detected (Table 1).

\section{Discussion}

The role of P2X7 in the regulation of bone turnover has already been established over the last decade. Extracellular nucleotides have been shown to be involved in calcium signalling and thus intercellular communication among osteoblasts [8]. Nevertheless, the reported effects of the relatively specific P2X7 agonist BzATP on the activity of bone cells in vitro have been conflicting $[12,18,19]$.

In the current study, we have shown that the P2X7 receptor has a distinct role in the regulation of bone mass and turnover, as BMD was increased in $\mathrm{P} 2 \mathrm{X}^{-/-}$mice from two strains with different genetic backgrounds. The mechanisms underlying the rise in BMD are presumably multiple but could be related to the observed changes in bone formation and resorption markers, even though no difference was seen in the histomorphometric analyses. 
TABLE 2: Histomorphometric analysis for B6 and BALB P2X7 $7^{+/+}$and $\mathrm{P} 2 \mathrm{X} 7^{-/-}$mice.

\begin{tabular}{|c|c|c|c|c|c|}
\hline B6 & & & & & $t$-Test \\
\hline Vertebrae & Mean & SEM & Mean & SEM & $P$ \\
\hline$N$ & & & & & \\
\hline MS/BS\% & 43.8 & 2.9 & 42.5 & 3.9 & 0.796 \\
\hline $\operatorname{MAR}(\mu \mathrm{m} /$ day $)$ & 1.07 & 0.03 & 1.00 & 0.04 & 0.077 \\
\hline ES/BS (\%) & 7.9 & 0.4 & 9.1 & 0.7 & 0.180 \\
\hline BV/TV (\%) & 17.7 & 1.5 & 20.4 & 0.9 & 0.122 \\
\hline Tb.Th. $(\mu \mathrm{m})$ & 32.8 & 1.1 & 36.5 & 0.7 & 0.011 \\
\hline C.Th. $(\mu \mathrm{m})$ & 93.0 & 3.6 & 93.7 & 4.8 & 0.917 \\
\hline Tibia & Mean & SEM & Mean & SEM & $P$ \\
\hline$N$ & & & & & \\
\hline MS/BS\% & 46.1 & 2.1 & 44 & 2.4 & 0.517 \\
\hline $\operatorname{MAR}(\mu \mathrm{m} /$ day $)$ & 1.16 & 0.03 & 1.2 & 0.04 & 0.378 \\
\hline ES/BS (\%) & 8.3 & 0.6 & 8.0 & 0.3 & 0.676 \\
\hline BV/TV (\%) & 10.0 & 1.7 & 13.2 & 1.7 & 0.197 \\
\hline Tb.Th. $(\mu \mathrm{m})$ & 32.3 & 1.1 & 35.5 & 1.7 & 0.138 \\
\hline C.Th. $(\mu \mathrm{m})$ & 127.4 & 3.8 & 162.6 & 6.1 & $<0.001$ \\
\hline $\mathrm{BALB} / \mathrm{cJ}$ & & & & & $t$-Test \\
\hline Tibia & Mean & SEM & Mean & SEM & $t$-Test \\
\hline$N$ & & & & & \\
\hline MS/BS\% & 44.8 & 5.7 & 53.4 & 4.1 & 0.267 \\
\hline $\operatorname{MAR}(\mu \mathrm{m} /$ day $)$ & 1.00 & 0.03 & ND & & - \\
\hline ES/BS (\%) & 10.15 & 0.5 & 9.9 & 0.9 & 0.791 \\
\hline BV/TV (\%) & 8.7 & 1.7 & 9.5 & 1.9 & 0.766 \\
\hline Tb.Th. $(\mu \mathrm{m})$ & 31.1 & 2.1 & 33.1 & 1.1 & 0.423 \\
\hline C.Th. $(\mu \mathrm{m})$ & 148.9 & 10.4 & 139.8 & 8.9 & 0.517 \\
\hline
\end{tabular}

Changes in histomorphometric parameters in $\mathrm{P} 2 \mathrm{X}^{-/-}$compared to $\mathrm{P} 2 \mathrm{X}^{+/+}$in the tibia and vertebral (only B6). Displayed as mean $\pm \mathrm{SE}$ for the group. The direction of changes is equal in the different regions of the B6 mice, besides MAR where it is decreased in the vertebral region of P2X7 ${ }^{-1-}$ and decreased in the tibia. The ES/BS (\%) has the opposite directions in vertebrae and tibia. Besides the cortical thickness and MS/BS (\%) the directions of changes are the opposite in the BALB mice compared to the B6 mice. The size of the changes in the histomorphometric parameters $\mathrm{P} 2 \mathrm{X}^{-1-}$ mice is different in relation to region and strain analyzed. Significant differences from wild type animals at the $P<0.05$ levels, determined by Student $t$-test, are displayed.

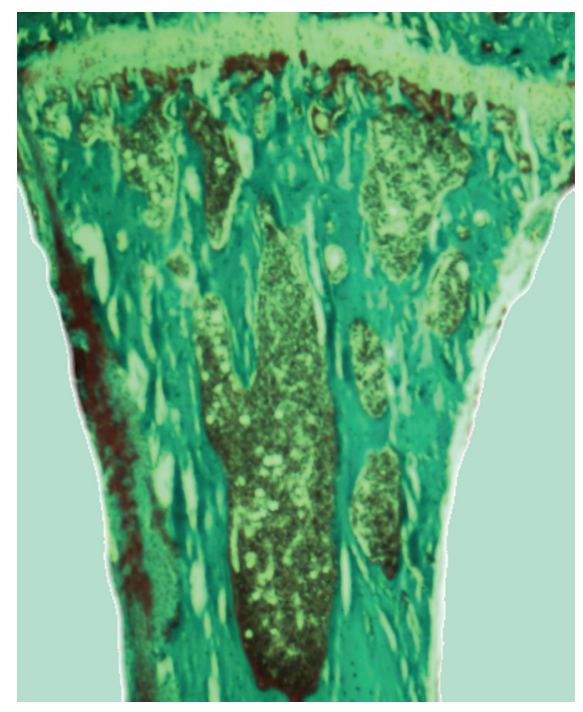

(a)

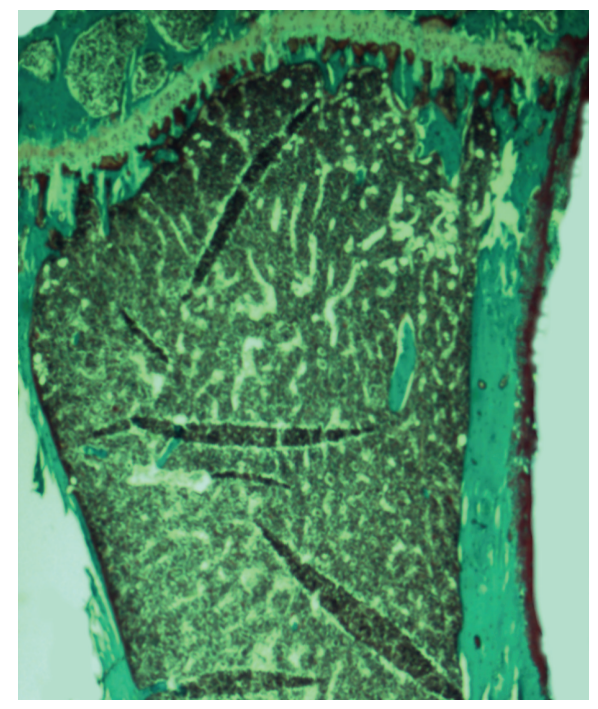

(b)

FIGURE 2: Representative photomicrographs of Goldner-Trichrome stained slices of proximal tibia from (a) P2X7 $7^{-/-}$and (b) wild type animals of B6 strain. 
The new $\mathrm{P} 2 \mathrm{X}^{-/-}$on BALB/cJ background (BALB $\mathrm{P} 2 \mathrm{X}^{-/-}$) showed significantly increased BMD, BMC, and bone area determined by DXA compared to the wild type genotype. BMD/BMC was also increased in the femoral region, which was accompanied by an increase in bone strength of the femoral diaphysis. The difference could be caused by reduced resorption compared to bone formation, since we found big reduction in s-CTX and a significant decrease in the bone formation marker alkaline phosphatase. Morphological changes in other compartments could also explain the observed results, but these have not been investigated in this study. Almost the same picture was present when the $\mathrm{B} 6 \mathrm{P} 2 \mathrm{X}^{-1-}$ mice were examined though the effect sizes were smaller. Thus, the increases in BMDs and in femoral strength were smaller. When histomorphometric analysis of the vertebrae was compared to the tibia, sitespecific differences were detected in the resorption index $\mathrm{ES} / \mathrm{BS} \%$, but even the effect was in the opposite direction; it was insignificant at both sites. The measured Tb.Th was significantly higher in the vertebrae but not in the tibia. We found increased C.Th in the proximal tibia, but not in the vertebrae. The fact that we observe the same effect of P2X7 ablation, but with a smaller effect size in the strain carrying the 451L allele, confirms the role of the P2X7 receptor in regulation of bone mass.

Serum CTX levels express the total bone resorbing activity of the organism, and interestingly we found striking differences in s-CTX between the two strains. In BALB/cJ, the wild type animals have a significantly higher s-CTX level than both the corresponding knock-out and the B6 wild type (Figure $1(\mathrm{~d})$ ). In contrast, the B6 wild type and the B6 P2X7 $7^{-/}$s-CTX levels are not different, suggesting a distinct role of the cytoplasmic tail of the P2X7 receptor in osteoclastic bone resorption. In a former study we found a reduction in pore formation in osteoclasts from the $\mathrm{B} 6$ strains compared to osteoclasts from the BALB/cJ, but no difference in resorptive activity of cultures not stimulated with nucleotides [30]. Even though there are multiple genetic differences between the two strains, the major finding in this study is that the genetic background is of significant importance when determining the effect of the P2X7 ablation.

As seen in Figure 2, our study confirms the results of the previous study where Gartland et al. showed increased cortical thickness in tibia of $\mathrm{P} 2 \mathrm{X}^{-/-}[22]$. Since they were not able to detect any difference in the formation and number of osteoclasts, they suggested that the apoptosis of the osteoblasts was affected. They also observed an increased number of osteocytes in cortex, suggesting that instead of undergoing apoptosis the osteoblasts were incorporated in matrix. That could be a plausible explanation for the differences found in $\mathrm{B} 6 \mathrm{P}^{2} 7^{-/-}$, but it cannot explain the decrease in s-CTX in the BALB P2X7 $7^{-/-}$. In the study by Ke et al., they found an increased number of osteoclasts in Pfizers DBA/B6 $\mathrm{P} 2 \mathrm{X}^{-/-}$tibiae but could not detect any difference in osteoclastogenesis in vitro [13]. Gartland et al. also reported that there was no significant difference in the development of osteoclasts between $\mathrm{B} 6 \mathrm{P} 2 \mathrm{X}^{-/-}$and $\mathrm{B} 6 \mathrm{WT}$ in vitro [22]. The question is if the unnatural culture conditions, for example, the lack of systemic hormones, accessory cells, and mechanical stimulation, could explain the lack of effect of P2X7 ablation upon osteoclasts when assessed in vitro compared to the differences seen in vivo/ex vivo.

Finally, the recently described P2X7-k splice variant suggested to escape knockout in the Glaxo mice [35] could be a contributing factor to the differences between the Glaxo and Pfizer models. However, even though normal osteoclasts express $\mathrm{P} 2 \mathrm{X} 7$, none could be detected in osteoclasts derived from $\mathrm{BALB} / \mathrm{cJ}-\mathrm{P} 2 \mathrm{X}^{-/-}$mice, indicating that the $\mathrm{P} 2 \mathrm{X} 7-\mathrm{k}$ expression splice variant was undetectable on the protein level [36].

However, even if there are some conflicting results from the two different models of P2X7 knock-out in mice, they both point towards an important role of the receptor in regulation of bone formation. It emphasizes that even though mice are widely used as models to study the regulation of bone mass and turnover, there are important differences between murine and human bone physiology. Human studies are highly warranted to investigate the role of the P2X7 receptor in human bone turnover and in conditions of altered bone metabolism.

The two background strains on which the B6xDBA $\mathrm{P} 2 \mathrm{X7}^{-/-}$from Pfizer and B6 P2X7 ${ }^{-/-}$from Glaxo mice were based carry the 451L allele of the naturally occurring mutation in P2X7. The contradictory effects on bone status between the two strains could be due to a number of factors, including differences in experimental parameters like sex, age, or diet $[13,22]$, which makes it difficult to compare the experiments with different background. Ke et al. found a larger effect of the knockout in DBA/B6 $\mathrm{P} 2 \mathrm{X}^{-/-}$males compared to the females. Gartland et al. do not inform about the sex of the B6 P2X7 animals in their study [22]. In our study, only females were used. Of critical importance is the choice of wild type animals, whether it is wild type siblings from heterozygote breeding couples or purchased from the inbred background strain. Another important parameter to consider is the diet, as it is known to influence bone mass and structure. Our earlier experiments with the B6 P2X7 mice showed only insignificant differences in s-CTX. By changing the diet from Altromin 1430 or 1319 to LabDiet 5K52, which contains more calcium $(0.8 \%$ to $1.15 \%)$, more D-vitamin ( $1 \mathrm{IU}$ to $4 \mathrm{IU}$ ), and less fat $(7.5 \%$ to $4 \%$ ) it showed significant effects on the BMD, also in female mice. In this study the BALB and $\mathrm{B} 6 \mathrm{P} 2 \mathrm{X}^{-/-}$mice were fed the same diet and had similar age and sex, so the only difference is the genetic background. Bouxsein et al. have shown that the genetic background is extremely important for the bone status in the different strains [33]. In this study BALB/cJ mice had higher bone turnover (indicated by levels of s-CTX and alkaline phosphatase) than B6. Therefore it is possible that it is easier to detect the decrease in resorption in the $\mathrm{P} \mathrm{X}^{-/-}$on the $\mathrm{BALB} / \mathrm{cJ}$ background. Similar strain-specific differences are seen in other knockout mice, like diverse effects of treatment are seen in different strains [37].

In conclusion, we have shown that the $\mathrm{P} 2 \mathrm{X} 7$ receptor plays an important role in the control of bone remodelling. Furthermore, absence of $\mathrm{P} 2 \mathrm{X} 7$ receptor expression seems to be associated with increased bone mass and strength in two 
mouse models. The effect of P2X7 ablation was underestimated in the model based on the B6 strain carrying the naturally occurring mutation, since the difference between the knockouts and their wild type littermates is higher in the BALB/c model than in the B6 model. Further studies are warranted in order to understand the complex roles of P2X7 in bone turnover, where especially human studies are important in order to fully understand the role of the receptor in human bone physiology.

\section{Acknowledgments}

The authors would like to acknowledge GlaxoSmithKline for providing the $\mathrm{B} 6 \mathrm{P} 2 \mathrm{X}^{-/-}$animals and the Bartholin Institute, Copenhagen Municipal Hospital for guidance and for housing the animals. The technical assistance of Zanne Henriksen and Zenia Sydow Abel was greatly appreciated. The work was kindly supported by the European Commission under the 7th Framework Programme (proposal no. 202231) performed as a collaborative project among the members of the ATPBone Consortium (Copenhagen University, University College London, University of Maastricht, University of Ferrara, University of Liverpool, University of Sheffield, and Université Libre de Bruxelles). The substudy belongs under the main study "Fighting osteoporosis by blocking nucleotides: purinergic signalling in bone formation and homeostasis." Furthermore, this work was funded by the Research Foundation on Hvidovre Hospital H:S, Denmark in 2003 and 2006.

\section{References}

[1] K. A. Buckley, S. L. Golding, J. M. Rice, J. P. Dillon, and J. A. Gallagher, "Release and interconversion of P2 receptor agonists by human osteoblast-like cells," FASEB Journal, vol. 17, no. 11, pp. 1401-1410, 2003.

[2] M. Romanello, B. Pani, M. Bicego, and P. D’Andrea, "Mechanically induced ATP release from human osteoblastic cells," Biochemical and Biophysical Research Communications, vol. 289, no. 5, pp. 1275-1281, 2001.

[3] F. Di Virgilio, P. Chiozzi, D. Ferrari et al., "Nucleotide receptors: an emerging family of regulatory molecules in blood cells," Blood, vol. 97, no. 3, pp. 587-600, 2001.

[4] S. J. Dixon and S. M. Sims, "P2 purinergic receptors on osteoblasts and osteoclasts: potential targets for drug development," Drug Development Research, vol. 49, no. 3, pp. 187-200, 2000.

[5] R. D. Graff, E. R. Lazarowski, A. J. Banes, and G. M. Lee, "ATP release by mechanically loaded porcine chondrons in pellet culture," Arthritis and Rheumatism, vol. 43, no. 7, pp. 15711579, 2000.

[6] J. P. Grierson and J. Meldolesi, "Shear stress-induced $\left[\mathrm{Ca}^{2+}\right](\mathrm{i})$ transients and oscillations in mouse fibroblasts are mediated by endogenously released ATP," Journal of Biological Chemistry, vol. 270, no. 9, pp. 4451-4456, 1995.

[7] K. Yamamoto, T. Sokabe, N. Ohura, H. Nakatsuka, A. Kamiya, and J. Ando, "Endogenously released ATP mediates shear stress-induced $\mathrm{Ca}^{2+}$ influx into pulmonary artery endothelial cells," American Journal of Physiology, vol. 285, no. 2, pp. H793-H803, 2003.

[8] N. R. Jørgensen, Z. Henriksen, O. H. Sørensen, E. F. Eriksen, R. Civitelli, and T. H. Steinberg, "Intercellular calcium signaling occurs between human osteoblasts and osteoclasts and requires activation of osteoclast P2X7 receptors," Journal of Biological Chemistry, vol. 277, no. 9, pp. 7574-7580, 2002.

[9] A. Hoebertz, A. Townsend-Nicholson, R. Glass, G. Burnstock, and T. R. Arnett, "Expression of P2 receptors in bone and cultured bone cells," Bone, vol. 27, no. 4, pp. 503-510, 2000.

[10] G. Collo, S. Neidhart, E. Kawashima, M. Kosco-Vilbois, R. A. North, and G. Buell, "Tissue distribution of the P2X7 receptor," Neuropharmacology, vol. 36, no. 9, pp. 1277-1283, 1997.

[11] L. N. Naemsch, S. J. Dixon, and S. M. Sims, "Activity-dependent development of P2X7 current and $\mathrm{Ca}^{2+}$ entry in rabbit osteoclasts," Journal of Biological Chemistry, vol. 276, no. 42, pp. 39107-39114, 2001.

[12] A. Gartland, R. A. Hipskind, J. A. Gallagher, and W. B. Bowler, "Expression of a P2X7 receptor by a subpopulation of human osteoblasts," Journal of Bone and Mineral Research, vol. 16, no. 5, pp. 846-856, 2001.

[13] H. Z. Ke, H. Qi, A. F. Weidema et al., "Deletion of the P2X7 nucleotide receptor reveals its regulatory roles in bone formation and resorption," Molecular Endocrinology, vol. 17, no. 7, pp. 1356-1367, 2003.

[14] N. Panupinthu, J. T. Rogers, L. Zhao et al., "P2X7 receptors on osteoblasts couple to production of lysophosphatidic acid: a signaling axis promoting osteogenesis," Journal of Cell Biology, vol. 181, no. 5, pp. 859-871, 2008.

[15] S. D. Ohlendorff, C. L. Tofteng, J.-E. B. Jensen et al., "Single nucleotide polymorphisms in the $\mathrm{P} 2 \mathrm{X} 7$ gene are associated to fracture risk and to effect of estrogen treatment," Pharmacogenetics and Genomics, vol. 17, no. 7, pp. 555-567, 2007.

[16] L. M. Zheng, A. Zychlinsky, C. C. Liu, D. M. Ojcius, and J. D. E. Young, "Extracellular APT as a trigger for apoptosis or programmed cell death," Journal of Cell Biology, vol. 112, no. 2, pp. 279-288, 1991.

[17] D. Ferrari, P. Chiozzi, S. Falzoni et al., "Extracellular ATP triggers IL-1 beta release by activating the purinergic $\mathrm{P} 2 \mathrm{Z}$ receptor of human macrophages," Journal of Immunology, vol. 159, no. 3, pp. 1451-1458, 1997.

[18] A. Gartland, K. A. Buckley, W. B. Bowler, and J. A. Gallagher, "Blockade of the pore-forming P2X7 receptor inhibits formation of multinucleated human osteoclasts in vitro," Calcified Tissue International, vol. 73, no. 4, pp. 361-369, 2003.

[19] J. Korcok, L. N. Raimundo, H. Z. Ke, S. M. Sims, and S. J. Dixon, "Extracellular nucleotides act through P2X7 receptors to activate NF- $\kappa \mathrm{B}$ in osteoclasts," Journal of Bone and Mineral Research, vol. 19, no. 4, pp. 642-651, 2004.

[20] R. A. North, "Molecular physiology of P2X receptors," Physiological Reviews, vol. 82, no. 4, pp. 1013-1067, 2002.

[21] A. Surprenant, F. Rassendren, E. Kawashima, R. A. North, and G. Buell, "The cytolytic P2Z receptor for extracellular ATP identified as a P2X receptor (P2X7)," Science, vol. 272, no. 5262, pp. 735-738, 1996.

[22] A. Gartland, K. A. Buckley, R. A. Hipskind et al., "Multinucleated osteoclast formation in vivo and in vitro by P2X 7 receptor-deficient mice," Critical Reviews in Eukaryotic Gene Expression, vol. 13, no. 2-4, pp. 243-253, 2003.

[23] J. F. Hiken and T. H. Steinberg, "ATP downregulates P2X7 and inhibits osteoclast formation in RAW cells," American Journal of Physiology, vol. 287, no. 2, pp. C403-C412, 2004.

[24] A. Agrawal, K. A. Buckley, K. Bowers, M. Furber, J. A. Gallagher, and A. Gartland, "The effects of P2X7 receptor antagonists on the formation and function of human osteoclasts in vitro," Purinergic Signalling, vol. 6, no. 3, pp. 307-315, 2010.

[25] M. S. Morrison, L. Turin, B. F. King, G. Burnstock, and T. R. Arnett, "ATP is a potent stimulator of the activation and 
formation of rodent osteoclasts," Journal of Physiology, vol. 511, no. 2, pp. 495-500, 1998.

[26] J. Li, D. Liu, H. Z. Ke, R. L. Duncan, and C. H. Turner, “The P2X7 nucleotide receptor mediates skeletal mechanotransduction," Journal of Biological Chemistry, vol. 280, no. 52, pp. 42952-42959, 2005.

[27] M. Solle, J. Labasi, D. G. Perregaux et al., "Altered cytokine production in mice lacking P2X7 receptors," Journal of Biological Chemistry, vol. 276, no. 1, pp. 125-132, 2001.

[28] I. P. Chessell, J. P. Hatcher, C. Bountra et al., "Disruption of the $\mathrm{P} 2 \mathrm{X} 7$ purinoceptor gene abolishes chronic inflammatory and neuropathic pain," Pain, vol. 114, no. 3, pp. 386-396, 2005.

[29] S. Adriouch, C. Dox, V. Welge, M. Seman, F. Koch-Nolte, and F. Haag, "Cutting edge: a natural P451L mutation in the cytoplasmic domain impairs the function of the mouse P2X7 receptor," Journal of Immunology, vol. 169, no. 8, pp. 41084112, 2002.

[30] S. Syberg, P. Schwarz, S. Petersen et al., "Association between $\mathrm{P} 2 \mathrm{X} 7$ receptor polymorphisms and bone status in mice," Journal of Osteoporosis. In press.

[31] H. Le Stunff, R. Auger, J. Kanellopoulos, and M. N. Raymond, "The Pro-451 to leu polymorphism within the C-terminal tail of P2X7 receptor impairs cell death but not phospholipase D activation in murine thymocytes," Journal of Biological Chemistry, vol. 279, no. 17, pp. 16918-16926, 2004.

[32] U. T. Iwaniec, D. Yuan, R. A. Power, and T. J. Wronski, "Straindependent variations in the response of cancellous bone to ovariectomy in mice," Journal of Bone and Mineral Research, vol. 21, no. 7, pp. 1068-1074, 2006.

[33] M. L. Bouxsein, K. S. Myers, K. L. Shultz, L. R. Donahue, C. J. Rosen, and W. G. Beamer, "Ovariectomy-induced bone loss varies among inbred strains of mice," Journal of Bone and Mineral Research, vol. 20, no. 7, pp. 1085-1092, 2005.

[34] F. Furlan, C. Galbiati, N. R. Jorgensen et al., "Urokinase plasminogen activator receptor affects bone homeostasis by regulating osteoblast and osteoclast function," Journal of Bone and Mineral Research, vol. 22, no. 9, pp. 1387-1396, 2007.

[35] A. Nicke, Y. H. Kuan, M. Masin et al., "A functional P2X7 splice variant with an alternative transmembrane domain 1 escapes gene inactivation in P2X7 knock-out mice," Journal of Biological Chemistry, vol. 284, no. 38, pp. 25813-25822, 2009.

[36] R. R. Hansen, C. K. Nielsen, A. Nasser et al., "P2X7 receptordeficient mice are susceptible to bone cancer pain," Pain, vol. 152, no. 8, pp. 1766-1776, 2011.

[37] D. Yan, A. Gurumurthy, M. Wright, T. W. Pfeiler, E. G. Loboa, and E. T. Everett, "Genetic background influences fluoride's effects on osteoclastogenesis," Bone, vol. 41, no. 6, pp. 10361044, 2007. 


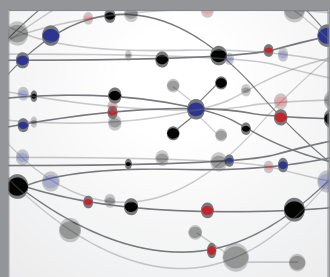

The Scientific World Journal
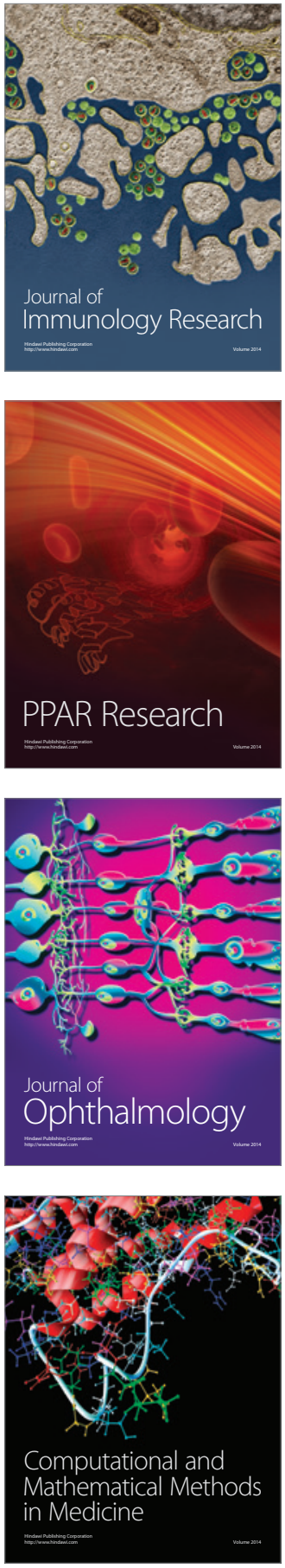

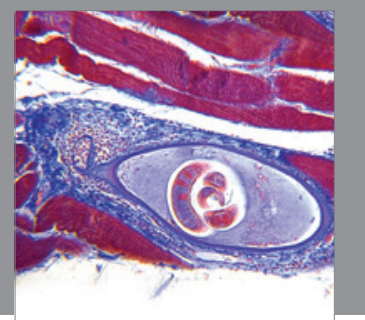

Gastroenterology

Research and Practice
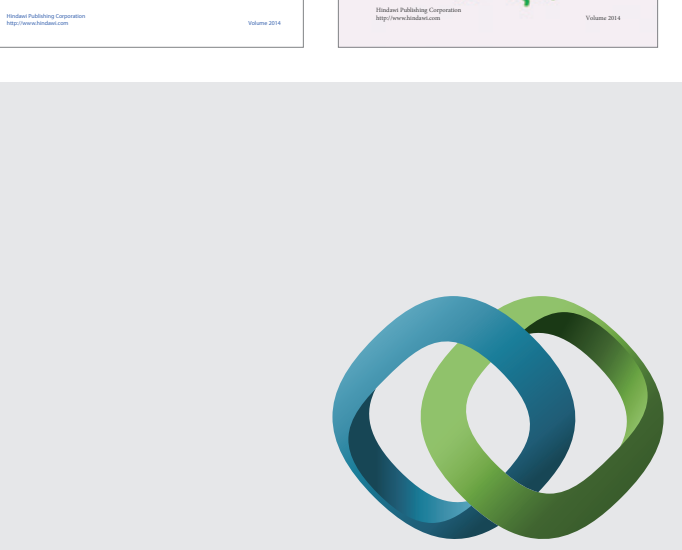

\section{Hindawi}

Submit your manuscripts at

http://www.hindawi.com
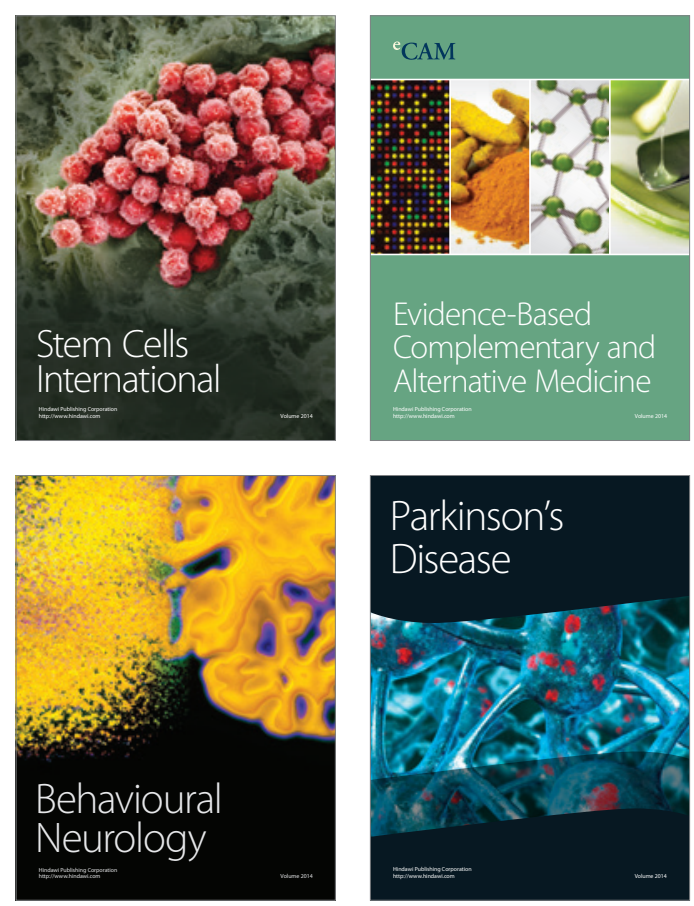

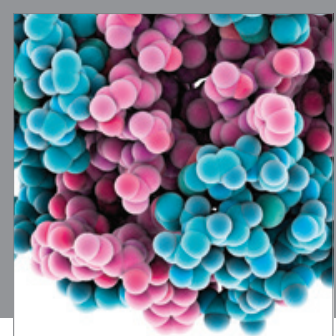

Journal of
Diabetes Research

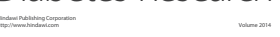

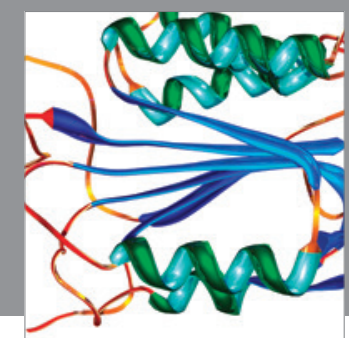

Disease Markers
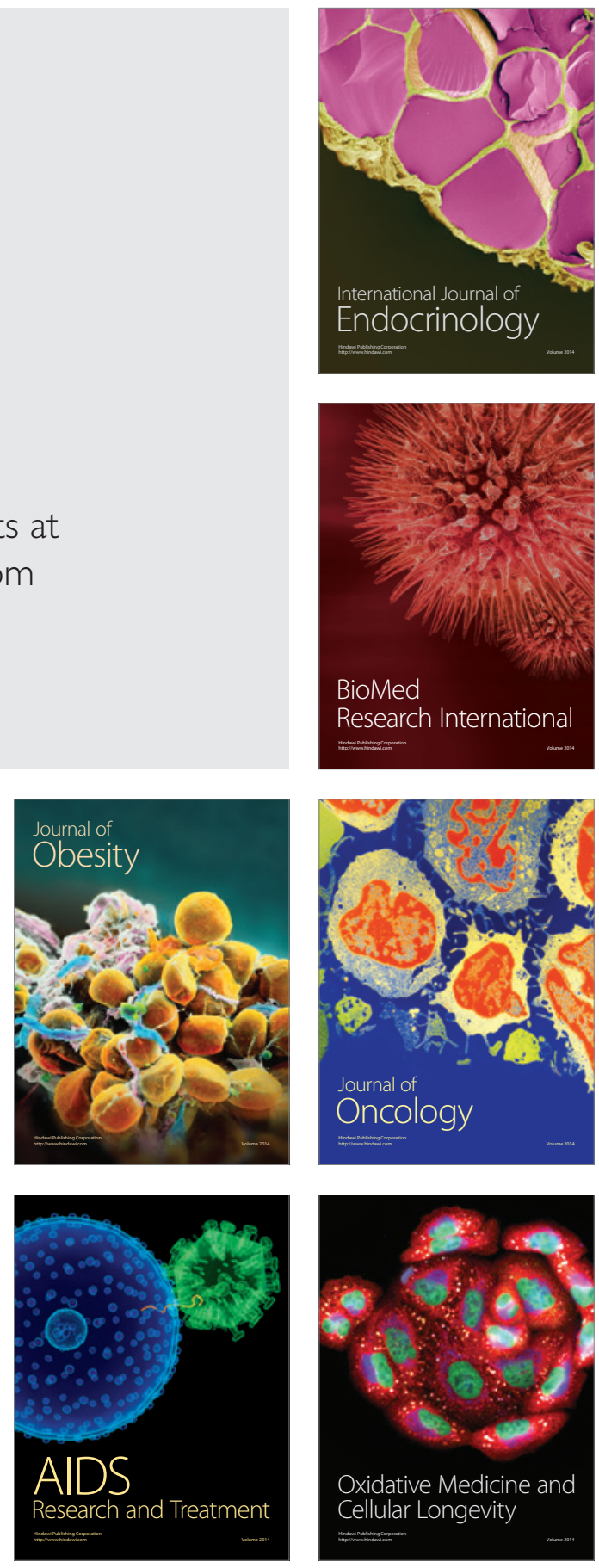